Article

\title{
Strobilurin Effects on Nitrogen Use Efficiency for the Yield and Protein in Durum Wheat Grown Under Rainfed Mediterranean Conditions
}

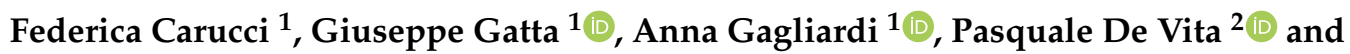 \\ Marcella Michela Giuliani ${ }^{1, *(\mathbb{D})}$ \\ 1 Department of Agricultural Food and Environmental Science, University of Foggia, 71122 Foggia, FG, Italy; \\ federica.carucci@unifg.it (F.C.); giuseppe.gatta@unifg.it (G.G.); anna.gagliardi@unifg.it (A.G.) \\ 2 Council for Agricultural Research and Economics, Research Centre for Cereal and Industrial \\ Crops (CREA-CI), 71122 Foggia, FG, Italy; pasquale.devita@crea.gov.it \\ * Correspondence: marcella.giuliani@unifg.it
}

Received: 10 August 2020; Accepted: 30 September 2020; Published: 3 October 2020

\begin{abstract}
In wheat, the increase in nitrogen use efficiency (NUE) and optimization of the nitrogen doses to be used are both very important aspects for improving sustainable and productive agriculture. The aim of this study was to investigate, under rainfed Mediterranean conditions, the influence of strobilurin treatment and $\mathrm{N}$ fertilization on durum wheat $\mathrm{N}$ use efficiency for yield (NUEy) and protein (NUEp) and on the contribution of their components, nitrogen uptake efficiency (UPE) and nitrogen utilization efficiency (NUtE). Two durum wheat cultivars (Saragolla and Sfinge) were grown for two years in field conditions under five nitrogen treatments $\left(60 \mathrm{~kg} \mathrm{ha}^{-1} \mathrm{~N} 60 ; 90\right.$ and $120 \mathrm{~kg} \mathrm{ha}^{-1}$ given two and three times; N90, N90T3, N120 and N120T3) comparing a control without strobilurin treatment (ST0) and one application of strobilurin (STaz). In Sfinge, STaz caused a decrease in UPE and NUEp and an increase in NUtE and NUEy. In Saragolla, the opposite behavior was observed. Moreover, strobilurin positively affected the contribution of UPE and negatively that of NUtE to NUEy only in Saragolla. Furthermore, strobilurin determined higher NUEy and NUEp values under most of the $\mathrm{N}$ treatments adopted in the drier year. With this study, we supported the hypothesis that in Mediterranean conditions, the possibility of reducing $\mathrm{N}$ rate application from 120 to $90 \mathrm{~kg} \mathrm{ha}^{-1}$ with a strobilurin-based treatment, even in the absence of fungal diseases, could represent a useful agronomic strategy for durum wheat grown under drought conditions as those predicted under the ongoing climate change.
\end{abstract}

Keywords: wheat; nitrogen fertilization; $\mathrm{N}$ uptake; $\mathrm{N}$ utilization; NUE; azoxystrobin

\section{Introduction}

Durum wheat (Triticum turgidum var. durum Desf.) is widely cultivated in the Mediterranean basin for making pasta, couscous, semolina and other products. Italy is one of the major producers in the world with almost 4.5 million tons [1]. Local wheat farmers operate in a harsh semi-arid environment, characterized by large inter-annual variability of precipitations [2]. These climatic conditions determine frequent drought and heat stress on rainfed durum wheat systems, with detrimental effects on spike and kernel formation, leading to large inter-annual yield fluctuations [3].

Under these climatic conditions, the main challenge for durum wheat farmers is to achieve the best trade-off between grain yield and protein content by optimizing the agronomic practices, especially regarding the choice of variety and the rationalization of nitrogen $(\mathrm{N})$ fertilization.

Nitrogen is one of the most important yield-limiting nutrients in crop production in all agro-ecological regions of the world, but it is also the most expensive. However, since only $30-40 \%$ 
of the nitrogen applied is generally absorbed and used by cereal plants [4], it also represents one of the major causes of pollution attributed to agriculture. In fact, the $\mathrm{N}$ applied and not utilized by the plants (about 60\%) is lost by leaching, denitrification and volatilization [5]. Finally, the synthesis of N fertilizers is a very expensive industrial process and contributes to global warming through nitrous oxide emissions [6].

Nitrogen use efficiency (NUE) is the fraction of applied nitrogen that is absorbed and used by the plant, therefore increasing NUE by optimizing the doses, and the $\mathrm{N}$ application time represents a very important strategy for improving sustainable and productive agriculture [7] On the contrary, limiting or excluding the application of $\mathrm{N}$ fertilizer in the cereal farming systems causes a reduction in the residual soil fertility with yield losses, insufficient inadequate quality standards and poor environmental sustainability [7].

Protein concentration is a critical factor determining grain quality and marketability in durum wheat since values equal or higher than $12 \%$ are requested from the pasta making industry; thus, together with the evaluation of the NUE for grain yield (NUEy), the evaluation of the NUE for grain proteins (NUEp) appears to be equally important for its role in high-quality pasta making. Both NUEy and NUEp may be subdivided into two components: nitrogen uptake efficiency and nitrogen utilization efficiency [8-10]. In the literature, NUE has been widely studied in bread wheat [11] while little information is available in durum wheat [12,13], especially regarding NUEp [9,10].

Recently, the use of substances as strobilurines, showing biostimulating actions on some metabolic and physiological processes, is providing a good strategy to improve the yield and grain quality. In fact, some strobilurines (e.g., azoxystrobin) are marketed as broad-spectrum fungicides with non-toxic effects for humans and the environment and with positive complementary effects on the yield and quality of different crops [14].

Strobilurins are natural antifungal antibiotics and were firstly isolated in 1977 from the mycelium of Strobilurus tenacellus, a saprobic Basidiomycete fungus causing wood-rotting on forest trees [15]. Strobilurin fungicides affect the electron transfer in the Krebs cycle of plant pathogenic fungi, and therefore halt the ATP production in mitochondrial respiration [16]. Therefore, they decrease ATPase activity, delaying proton $(\mathrm{H}+)$ pumping to the apoplast, subsequently causing a decrease in cytosol $\mathrm{pH}$ [17]. Besides the traditional utilization in plant protection, foliar application of strobilurins demonstrated to positively affect plant physiological processes such as photosynthetic activity, ethylene biosynthesis and the stomatal opening [16,18]. Another effect of strobilurins on plant physiology concerns the increase in the activity of NADH-nitrate reductase, which catalyzes the first stage of plant nitrate assimilation [17]. Ruske et al. [19] in a study on bread wheat reported that the $\mathrm{N}$ uptake increased after strobilurin application, as well as $\mathrm{N}$ harvest index (NHI) and the net $\mathrm{N}$ remobilization from vegetative tissues to the grain. Moreover, Goodig et al. [20,21] reported that strobilurin fungicides improved NUE of different wheat varieties compared to untreated plots, enhancing the recovery of late-season $\mathrm{N}$ fertilizers, with also a significant increase in NHI. Finally, of special interest is the increase in biomass and yield achieved by application of strobilurin, even in plants not infected by fungi [22].

In order to fill the knowledge gap on NUE between bread and durum wheat, the aim of this study was to investigate the effects of strobilurin treatment and N fertilization on NUEy, NUEp and their components on two durum wheat cultivars. We aim at providing ready-to-use indications on the possible benefits connected to strobilurin application on durum wheat regarding the standard $\mathrm{N}$ management strategies used in semi-arid areas such as southern Italy.

\section{Materials and Methods}

\subsection{Field Trial}

Field experiments were conducted in Foggia, southern Italy, $\left(41^{\circ} 46^{\prime} \mathrm{N}, 16^{\circ} 54^{\prime} \mathrm{E}\right)$. The study was carried out over 2 years, 2010-2011 and 2011-2012 (namely, 2011 and 2012, respectively). Two cultivars, Saragolla (Syngenta Seeds AG, Basel, Switzerland) and Sfinge (CREA-CI, Foggia, Italy), both of them 
maturing early genotypes, were grown on a clay loam soil (United States Department of Agriculture Classification, Washington, DC, USA) (Table 1).

The two cultivars were chosen based on their respective qualitative and quantitative traits. Saragolla is a high-yielding variety with a medium grain protein content, while Sfinge is a variety that combines a high protein content with a medium yield potential. The experiment was sown on 18 and 17 November 2010 and 2011, respectively, with a seeding rate of 350 germinable seeds per square meter; the preceding crop was durum wheat. Five nitrogen treatments were evaluated: 60,90 and $120 \mathrm{~kg} \mathrm{ha}^{-1}$ (N60, N90 and N120) given two times according to the N fertilization strategy used in southern Italy [23], and 90 and $120 \mathrm{~kg} \mathrm{ha}^{-1}$ (N90T3 and N120T3), given three times from pre-sowing to flag leaf appearance, as reported in Table 2.

Table 1. Main soil physical and chemical properties relative to the two years under examination.

\begin{tabular}{cccc}
\hline Soil Proprieties & Unit of Measurement & $\mathbf{2 0 1 1}$ & $\mathbf{2 0 1 2}$ \\
\hline Sand & $\%$ & 35.2 & 31.7 \\
Silt & $\%$ & 31.1 & 36.2 \\
Clay & $\%$ & 33.7 & 32.1 \\
Total N (Kjeldhal method) & $\%$ oo & 1.16 & 1.15 \\
Available P (Olsen method) & $\mathrm{mg} \mathrm{kg}^{-1}$ & 80 & 81 \\
Exchangeable K (Ammonium acetate method) & $\mathrm{mg} \mathrm{kg}^{-1}$ & 461 & 450 \\
Organic matter (Walkley-Black method) & $\%$ & 2.20 & 2.50 \\
\hline
\end{tabular}

Table 2. Nitrogen fertilizer application management.

\begin{tabular}{|c|c|c|c|}
\hline Nitrogen Application & Pre-Sowing & Tillering & Flag Leaf Appearance \\
\hline & $\begin{array}{c}\text { Biammonium Phosphate } \\
(18 \% \mathrm{~N})\end{array}$ & $\begin{array}{c}\text { Urea } \\
(46 \% \mathrm{~N})\end{array}$ & $\begin{array}{c}\text { Ammonium Nitrate } \\
(27 \% \mathrm{~N})\end{array}$ \\
\hline & \multicolumn{3}{|c|}{$\left(\mathrm{kg} \mathrm{ha}^{-1}\right)$} \\
\hline N60 & 36 & 24 & - \\
\hline N90 & 36 & 54 & - \\
\hline N90T3 & 36 & 27 & 27 \\
\hline N120 & 36 & 84 & - \\
\hline N120T3 & 36 & 54 & 30 \\
\hline
\end{tabular}

In addition, the strobilurin fungicide effect was evaluated by comparing (i) ST0, control without strobilurin and (ii) STaz, with one application of azoxystrobin, at a rate of $1 \mathrm{~L} \mathrm{ha}^{-1}$ at the flag leaf appearance stage (BBCH stage 41) [24], applied using a hand-held knapsack sprayer.

The experiment was arranged as a split-split plot design with three replications: the cultivar was the main plot, $\mathrm{N}$ fertilization was the plot, and strobilurin application was the sub-plot (10.2 square meter).

All agricultural practices applied to durum wheat crop during the two years were performed according to the agronomic techniques commonly adopted by local farmers. Weeds were controlled by means of specific herbicides: Tralcossidim $\left(1.7 \mathrm{~L} \mathrm{ha}^{-1}\right)+$ Clopyralid + MCPA + Fluroxypyr $\left(2.0-2.5 \mathrm{~L} \mathrm{ha}^{-1}\right)$.

Durum wheat grain was machine-harvested at full maturity (BBCH 91-92) [24] on 14 and 5 June in 2011 and 2012, respectively. During the experimental period, the daily climatic parameters of rainfall and temperature were recorded by a weather station near the experimental area.

\subsection{SPAD Measurements}

The chlorophyll meter SPAD-502 (SPAD, Kelana Jaya, Malaysia; Konica Minolta Holdings Inc.-Tokyo, Japan) was utilized to determine the relative amount of leaf chlorophyll at different growth stages. Measurements were recorded as mean value of 10 randomly selected main tiller per plot, 
taken as approximately one-third of the length from the base of the youngest fully expanded leaf $[25,26]$. The measurements were performed at about the same time (middle day).

For each cultivar, six SPAD measurements were collected during the two crop cycles: stem elongation phase (SPAD1; BBCH stage 31-39), flag leaf (SPAD2; BBCH stage 41), heading date (SPAD3; BBCH stage 53-59), flowering (SPAD 4; BBCH stage 63-67), development of grain to early-late milk (SPAD 5; BBCH stage 72-78) and ripening-soft dough (SPAD 6; BBCH stage 80-86) [24]. According to Noulas et al. [25], the SPAD values were used as a direct measure of leaf greenness because the plant material tested was restricted to a single crop species.

\subsection{Yield, Protein Content, Nitrogen Plant Content and N Use Efficiency Indices}

At harvest time, the grain yield ( $\mathrm{t} \mathrm{ha} \mathrm{a}^{-1}$ ) (GY) was assessed for each plot. Grain protein content (GPC) was also determined by near-infrared reflectance spectroscopy, using an Infratec 1229 grain analyzer (Foss Tecator, Hillerød, Denmark).

In each experimental year, at physiological maturity (BBCH stage 87), plant samples were taken from 0.5 linear meter of two adjacent rows, cutting-off the shoots at the crown level. Dry matter was determined by drying the sampled plants in an oven at $65^{\circ} \mathrm{C}$ to constant weight. Subsequently, all samples were ground using a Cyclotec Sample Mill 1093 (Foss Tecator, Hillerød, Denmark). Nitrogen concentration of straw and grain was determined in triplicate by the Kjeldhal method using a Kjeltec Analyzer Unit 2300 (Foss Tecator, Hillerød, Denmark).

The straw and grain $\mathrm{N}$ content were calculated by multiplying the dry weight by the concentration of $\mathrm{N}$ of each fraction; finally, the plant's $\mathrm{N}$ content was the sum of the $\mathrm{N}$ content of the straw and grain. According to Lopez-Bellido et al. [27] and Giuliani et al. [10] the following $\mathrm{N}$ efficiency parameters were calculated:

- $\quad \mathrm{N}$ use efficiency for grain yield (NUEy; $\mathrm{kg} \mathrm{kg}^{-1}$ ) as the ratio of grain yield to the $\mathrm{N}$ fertilizer applied;

- $\quad \mathrm{N}$ use efficiency for protein (NUEp; $\mathrm{kg} \mathrm{kg}^{-1}$ ) as the ratio of grain $\mathrm{N}$ content to $\mathrm{N}$ fertilizer applied;

- $\quad \mathrm{N}$ uptake efficiency (UPE; $\mathrm{kg} \mathrm{kg}^{-1}$ ) as the ratio of plant $\mathrm{N}$ content to the $\mathrm{N}$ fertilizer applied;

- $\quad \mathrm{N}$ utilization efficiency (NUtE; $\mathrm{kg} \mathrm{kg}^{-1}$ ) as the ratio of grain yield to plant $\mathrm{N}$ content;

- $\quad \mathrm{N}$ harvest index (NHI; $\mathrm{kg} \mathrm{kg}^{-1}$ ) as the ratio of grain $\mathrm{N}$ content to plant $\mathrm{N}$ content.

NUEy was partitioned into the component UPE and NUtE, and NUEp into the components UPE and NHI $[8,10,28]$.

\subsection{Statistical Analysis}

The dataset was tested according to the basic assumptions of analysis of variance (ANOVA). The normal distribution of the experimental error and the common variance of the experimental error were verified through Shapiro-Wilk and Levene's tests, respectively. According to Levene's test of significance $(p \leq 0.05)$, the ANOVA procedure was performed separately for the two experimental years. When required, Box-Cox transformations [29] were applied prior to analysis. The ANOVA model was performed according to a split-split plot design with three replicates considering cultivar, nitrogen fertilization, strobilurin treatment and their interactions (cultivar $\times$ nitrogen fertigation, cultivar $\times$ strobilurin treatment, nitrogen fertilization $\times$ strobilurin treatment and cultivar $x$ nitrogen fertigation $\times$ strobilurin treatment). All the factors were considered as fixed, while the replicates as random. The statistical significance of the difference among the means was determined using Tukey's honest significance difference post hoc test at the $5 \%$ probability level.

In order to evaluate the effect of strobilurin on the relation between NUEy and its component (UPE and NUtE) and between NUEp and its component (UPE and NHI), the analysis of covariance (ANCOVA) was performed on In-transformed data. According to this procedure, the NUE components (ln UPE, ln NUtE and $\ln \mathrm{NHI}$ ), considered as the dependent variables $(\mathrm{Y})$, were processed through a linear model, where ln NUEy and ln NUEp were used as the regressor ( $X$, continuous numerical variable), and strobilurin treatment was the covariate (categorical variable). The sum of the angular 
coefficients of the regressed components was equal to unity thus explaining the complementary contribution of each component to NUEy and NUEp, respectively $[10,30]$.

ANOVA analysis was performed using "the lme4 package" of the " $R$ " statistical software, version 3.6.3 [31]; moreover, graphs were generated with "ggplot2" [32]. Finally, ANCOVA analysis was performed using the JMP software package, version 14.3 (SAS Institute Inc., Cary, NC, USA).

\section{Results}

\subsection{Weather Conditions}

The first year was characterized by higher rainfall compared to the second one, both during the vegetative and the grain-filling period (Table 3 and Figure S1). During the first year, intense rainfall events were recorded in the third 10 days of January, in the second 10 days of February and in the first 10 days of March. As for the grain-filling period, in the first year, higher and well distributed rainfall occurred. On the contrary, in the second year, only $21 \mathrm{~mm}$ of rainfall felt, the most of which concentrated in four days during the second 10 days of May. During the two growing seasons, the trends of temperature $(\mathrm{T})$ were quite mild compared to long-term averages and similar in the two crop seasons. Due to the dry weather conditions of the two years, the incidence of fungal diseases was completely negligible or zero. However due to the low rainfall, the second growing season was drier than the first one.

Table 3. Climatic data related to the two experimental years.

\begin{tabular}{cccc}
\hline & & $\mathbf{2 0 1 1}$ & $\mathbf{2 0 1 2}$ \\
\hline Crop cycle duration from sowing & days & 209 & 201 \\
Crop cycle rainfall & $\mathrm{mm}$ & 362.2 & 242.1 \\
From seeding to heading rainfall & $\mathrm{mm}$ & 302.6 & 220.9 \\
Grain filling rainfall & $\mathrm{mm}$ & 59.6 & 21.2 \\
Crop cycle mean T & ${ }^{\circ} \mathrm{C}$ & 11.4 & 10.7 \\
Grain filling mean T & ${ }^{\circ} \mathrm{C}$ & 18.1 & 17.4 \\
Grain filling mean T max & ${ }^{\circ} \mathrm{C}$ & 24.2 & 25.7 \\
\hline
\end{tabular}

\subsection{SPAD Measurements}

In the two years, SPAD readings were performed six times from stem elongation (control, before strobilurin and the third nitrogen application) to soft-ripening (Figure 1). In 2011, the SPAD values began to decrease from the flowering stage (SPAD4) and gradually to the end (soft ripening; SPAD6). Instead, in 2012, the values began to decrease later, from development of fruit to early-late milk (SPAD5), and then, they dropped drastically until SPAD6.

Clear differences were observed among the cultivars (Figure 1a): Sfinge, in general, showed higher SPAD values than Saragolla. In 2011, no significant difference was observed between the cultivars at stem elongation (SPAD1), but the differences increased after strobilurin application until maturity (SPAD6). In 2012, the differences between Sfinge and Saragolla were less evident.

In regard to $\mathrm{N}$ fertilization, in 2011, as expected, from the first to the last readings, higher SPAD values were observed under higher $\mathrm{N}$-fertilization levels, decreasing from 45.4 to 11.8 for N60, from 49.4 to 15.9 for N90, from 48.3 to17.9 for N90T3, from 52.1 to 17.2 for N120, and from 49.4 to 19.0 for N120T3. At the last reading, SPAD values decreased regularly, but N90T3 and N120T3 decreased less, showing higher SPAD values at the end of the cycle. In 2012, the differences among the N fertilization levels in the time course of SPAD readings were less evident when compared to 2011. The SPAD values decreased regularly, except for the third N split application plot (N90T3 and N120T3) where SPAD values slight increased during the heading (SPAD3) and anthesis (SPAD4) stages. Moreover, in 2012, the last SPAD readings, $90 \mathrm{~T} 3$ and 120T3, showed higher values (Figure $1 \mathrm{~b}$ ). In both years, a positive effect of strobilurin application was evident. In 2011, significant higher values under STaz occurred, 
starting from the flowering stage (SPAD4), while in 2012, the positive effect was evident soon after strobilurin application (flag leaf, SPAD2) (Figure 1c).
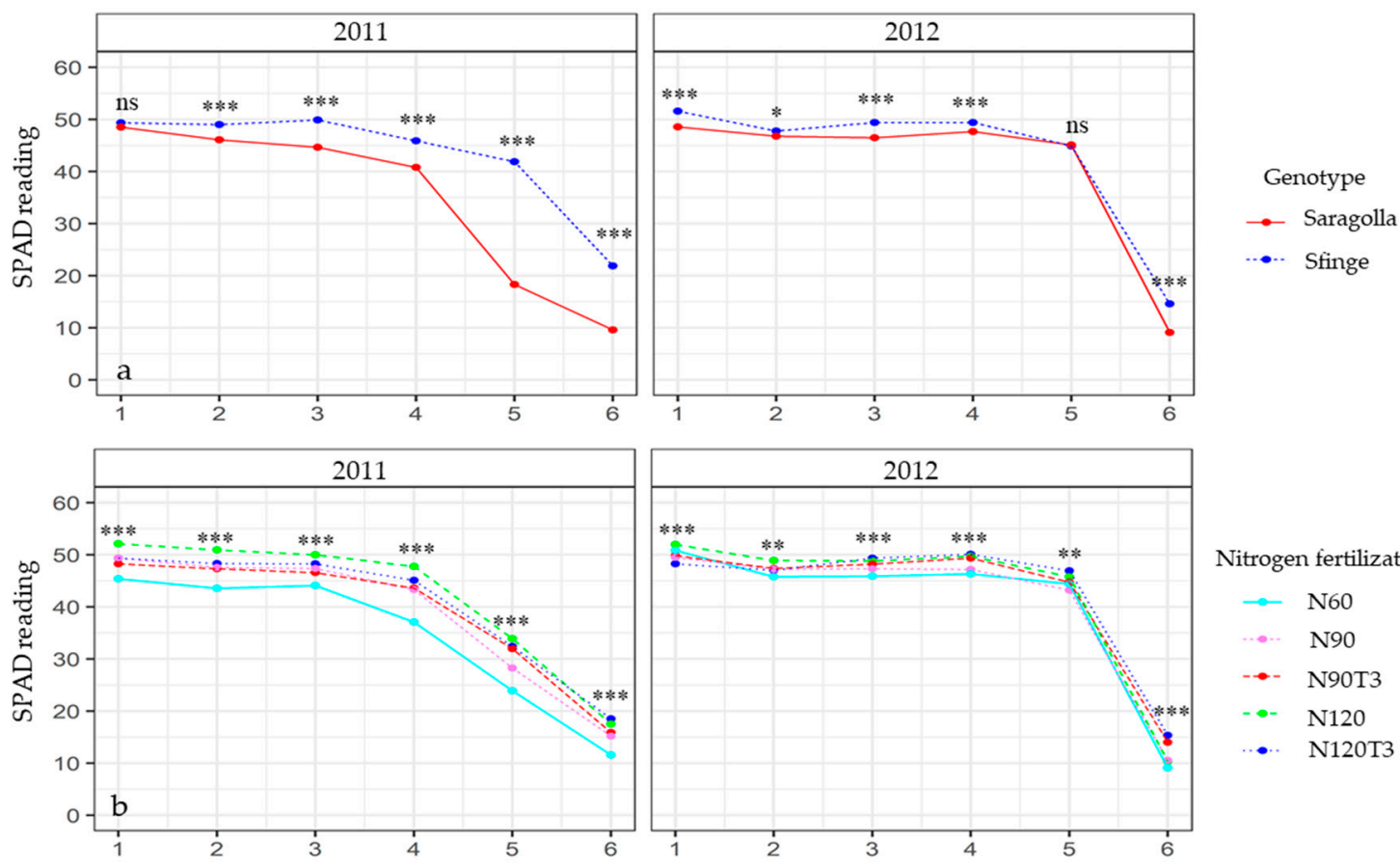

Nitrogen fertilization

$\because \mathrm{N} 60$

N90

N90T3

- N120

... N120T3
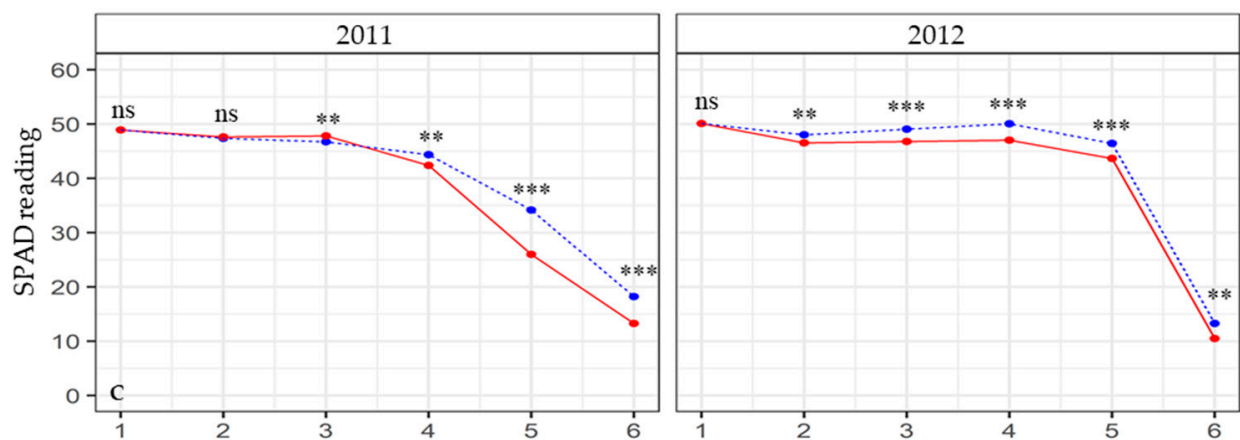

Strobilurin treatment

$\because$ STO

-.. STaz

Figure 1. Effect of cultivar (a), nitrogen fertilization (b) and strobilurin treatment (c) on SPAD readings during the two growing seasons (2011 and 2012) from stem elongation to soft-ripening. $1=$ SPAD1 (BBCH 31-39). 2 = SPAD2 (BBCH 41); 3=SPAD3 (BBCH 53-59); 4 = SPAD4 (BBCH 63-67); 5 = SPAD5 (BBCH 72-78); 6 = SPAD6 (BBCH 80-86) [24]. N60, N90 and N120 correspond to 60, 90 and $120 \mathrm{~kg} \mathrm{ha}^{-1}$ of nitrogen applied two times; N90T3, $90 \mathrm{~kg} \mathrm{ha}^{-1}$ of nitrogen applied three times; N120T3, $120 \mathrm{~kg} \mathrm{ha}^{-1}$ of nitrogen applied three times. ST0, no strobilurin treatment; STaz, strobilurin treatment. ${ }^{* *}$, significant at $p \leq 0.01,{ }^{* * *}$, significant at $p \leq 0.001 ;$ ns, not significant.

\subsection{N Content in the Plant, Straw and Grain}

The results of the ANOVA, performed on the two years on plant, straw and grain $\mathrm{N}$ content are reported in (Supplementary Material Table S1). Sfinge showed higher values of plant, straw and grain $\mathrm{N}$ content than Saragolla in both years. The differences between the two genotypes were more marked in 2011 than in 2012 (Table 4). In the first year, $\mathrm{N}$ fertilization caused an increase in plant and straw $\mathrm{N}$ content with increasing $\mathrm{N}$ levels. The same trend was observed for grain $\mathrm{N}$ content with higher values under N90T3 than under N90 in both cultivars and only for Saragolla also under N120T3 than under N120 (Table S2). On the contrary, in the second year, the highest values of plant, straw and grain N content were observed under N60, and the three-time fertilization (N90T3 and N120T3) always had a negative effect on both cultivars (Table S2). Finally, in the first year, strobilurin treatment caused a 
decrease in plant and straw $\mathrm{N}$ content and an increase in grain $\mathrm{N}$ content, while in the second year, both grain and plant $\mathrm{N}$ content increased under STaz.

Table 4. Effect of cultivar, nitrogen fertilization and strobilurin treatment in 2011 and 2012 for plant, straw and grain $\mathrm{N}$ content $\left(\mathrm{kg} \mathrm{kg}^{-1}\right)$.

\begin{tabular}{|c|c|c|c|c|c|c|}
\hline \multirow{3}{*}{$\begin{array}{c}\text { Experimental } \\
\text { Factor }\end{array}$} & \multicolumn{6}{|c|}{ Crop Season } \\
\hline & \multicolumn{3}{|c|}{2011} & \multicolumn{3}{|c|}{2012} \\
\hline & Plant & Straw & Grain & Plant & Straw & Grain \\
\hline & \multicolumn{6}{|c|}{ Cultivar } \\
\hline Saragolla & $133.3 \pm 7.9^{b}$ & $68.1 \pm 3.9^{b}$ & $65.2 \pm 4.4^{\mathbf{b}}$ & $121.4 \pm 3.8^{\mathbf{b}}$ & $55.01 \pm 1.6^{\mathbf{b}}$ & $66.35 \pm 2.3^{b}$ \\
\hline \multirow[t]{2}{*}{ Sfinge } & $273.9 \pm 11.4^{\mathbf{a}}$ & $195.9 \pm 9.7^{\mathrm{a}}$ & $78.0 \pm 2.0^{\mathrm{a}}$ & $141.2 \pm 2.6^{\mathrm{a}}$ & $72.30 \pm 1.3^{a}$ & $68.89 \pm 1.5^{\mathrm{a}}$ \\
\hline & \multicolumn{6}{|c|}{ Nitrogen Fertilization } \\
\hline N60 & $146.2 \pm 16.5^{\mathrm{d}}$ & $92.4 \pm 12.6^{\mathrm{d}}$ & $53.8 \pm 4.0^{\mathbf{e}}$ & $147.4 \pm 6.5^{a}$ & $71.1 \pm 4.5^{\mathrm{a}}$ & $76.31 \pm 2.9^{a}$ \\
\hline N90 & $201.0 \pm 30.1^{\mathrm{c}}$ & $134.9 \pm 25.5^{\mathrm{c}}$ & $66.1 \pm 5.1^{\mathrm{d}}$ & $126.1 \pm 7.3^{d}$ & $62.2 \pm 3.5^{c}$ & $63.92 \pm 4.1^{\mathrm{d}}$ \\
\hline N90T3 & $213.8 \pm 30.4^{\mathbf{b}}$ & $142.0 \pm 25.6^{\mathbf{b}}$ & $71.8 \pm 5.7^{\mathrm{c}}$ & $119.9 \pm 3.2^{\mathbf{e}}$ & $58.8 \pm 2.7^{\mathrm{d}}$ & $61.12 \pm 1.7^{\mathrm{e}}$ \\
\hline N120 & $228.2 \pm 18.6^{\mathrm{a}}$ & $146.3 \pm 18.7^{\mathrm{a}}$ & $81.9 \pm 1.6^{\mathbf{b}}$ & $134.1 \pm 2.7^{\mathbf{b}}$ & $63.5 \pm 2.1^{\mathbf{b}}$ & $70.55 \pm 1.0^{\mathbf{b}}$ \\
\hline \multirow[t]{2}{*}{ N120T3 } & $228.8 \pm 25.6^{\mathrm{a}}$ & $144.5 \pm 24^{\mathrm{ab}}$ & $84.3 \pm 6.5^{\mathrm{a}}$ & $129.0 \pm 5.5^{c}$ & $62.7 \pm 3.4^{b c}$ & $66.22 \pm 2.7^{c}$ \\
\hline & \multicolumn{6}{|c|}{ Strobilurin Treatment } \\
\hline ST0 & $211.0 \pm 21.1^{a}$ & $143 \pm 17.8^{a}$ & $68.0 \pm 3.9^{b}$ & $129.5 \pm 4.3^{\mathbf{b}}$ & $63.39 \pm 2.4^{a}$ & $66.12 \pm 2.1^{b}$ \\
\hline STaz & $196.2 \pm 9.3^{b}$ & $121 \pm 8.1^{b}$ & $75.2 \pm 3.24^{\mathrm{a}}$ & $133.0 \pm 3.0^{a}$ & $63.92 \pm 2.0^{a}$ & $69.13 \pm 1.8^{a}$ \\
\hline
\end{tabular}

N60, N90 and N120 correspond to 60, 90 and $120 \mathrm{~kg} \mathrm{ha}^{-1}$ of nitrogen applied two times, respectively; N90T3, $90 \mathrm{~kg} \mathrm{ha}^{-1}$ of nitrogen applied three times; N120T3, $120 \mathrm{~kg} \mathrm{ha}^{-1}$ of nitrogen applied three times. ST0, no strobilurin treatment; STaz, strobilurin treatment. For each experimental factor, values in the column followed by different letters are significantly different at $p \leq 0.05$ according to Tukey's test. Data are reported as means \pm standard errors.

However, the effect of strobilurin treatment was different in relation to the two cultivars under examination and to the different $\mathrm{N}$ fertilization applied. In Figure 2 the interactions betweencultivar and strobilurin treatment for the two years are reported. In 2011, for Saragolla, strobilurin treatment caused a significant increase in $\mathrm{N}$ content both in straw and in grain; as consequence, also plant $\mathrm{N}$ content was higher under STaz. On the contrary, for the Sfinge cultivar, STaz had a negative effect, determining a decrease in N content in straw content and grain (Figure 2A). In 2012, the two cultivars confirmed the same behavior observed in 2011, with strobilurin treatment showing a positive effect on Saragolla and a negative effect on Sfinge (Figure 2B). The interactions between $\mathrm{N}$ fertilization and strobilurin treatment, evaluated for the two years, are reported in Table 5. In 2011, the negative effect of strobilurin treatment on the $\mathrm{N}$ content of plant and straw was significant under N90 and N120. On the contrary, the strobilurin caused a significant increase in the grain $\mathrm{N}$ content under $\mathrm{N} 60$, whereas under N90 and N120, the effect was significant only when given three times (N90T3 and N120T3). In 2012, the STaz caused a significant increase in plant, straw and grain N content under N60, N90 and N120T3. 

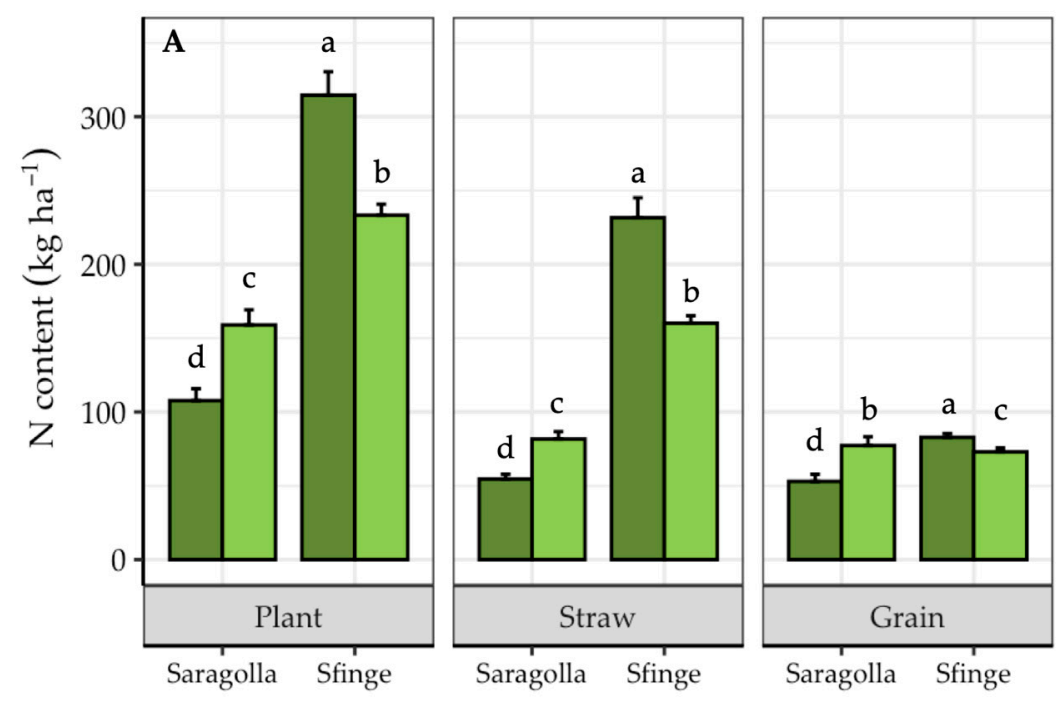

Strobilurin treatment
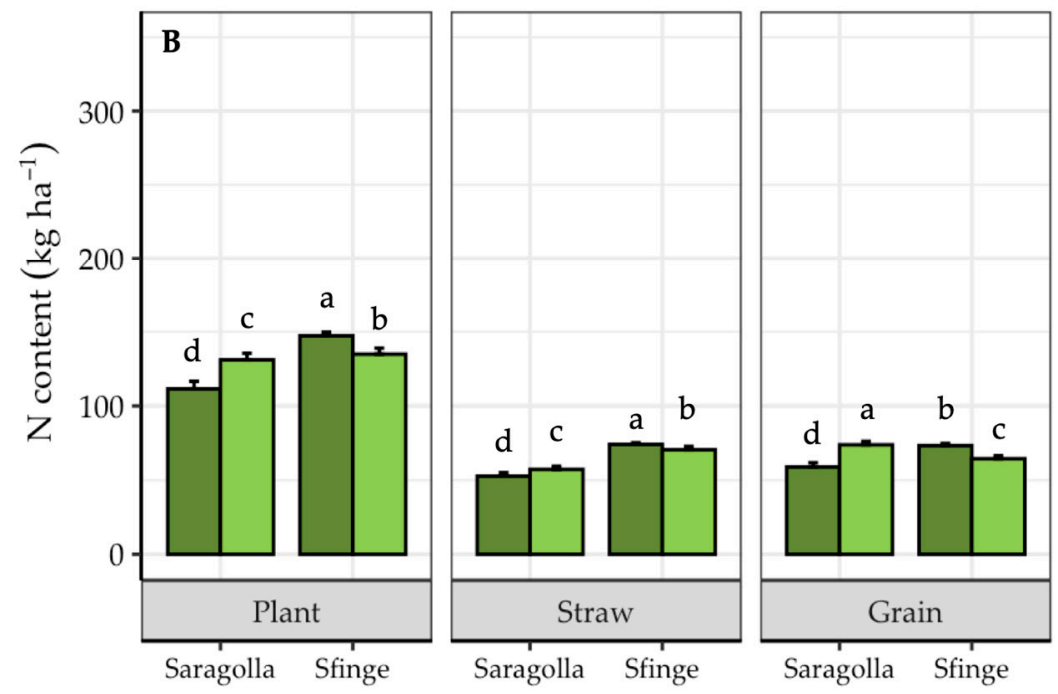

Strobilurin treatment

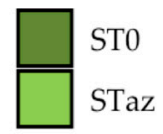

Figure 2. Effect of the interactions between cultivar and strobilurin treatment in 2011 (A) and 2012 (B) for plant, straw and grain N content. ST0, no strobilurin treatment; STaz, strobilurin treatment. Values with different letters are significantly different at $p \leq 0.05$ according to Tukey's test. Vertical bars indicate standard errors $(n=15)$. 
Table 5. Effect of the interactions between nitrogen fertilization and strobilurin treatment in 2011 and 2012 for plant, straw and grain $\mathrm{N}$ content ( $\mathrm{kg} \mathrm{kg}^{-1}$ )

\begin{tabular}{|c|c|c|c|c|c|c|c|c|c|c|}
\hline \multirow[t]{3}{*}{$\begin{array}{l}\text { Crop } \\
\text { Season }\end{array}$} & \multicolumn{10}{|c|}{ Strobilurin Treatment } \\
\hline & \multicolumn{5}{|c|}{ ST0 } & \multicolumn{5}{|c|}{ STaz } \\
\hline & N60 & N90 & N90T3 & N120 & N120T3 & N60 & N90 & N90T3 & N120 & N120T3 \\
\hline & \multicolumn{10}{|c|}{2011} \\
\hline Plant & $135.2 \pm 28.2^{f}$ & $221.9 \pm 57.4^{\mathbf{b}}$ & $215.9 \pm 55.2^{b c}$ & $243.0 \pm 37.4^{\mathrm{a}}$ & $239.7 \pm 53.1^{a}$ & $157.3 \pm 18.6^{\mathbf{e}}$ & $180.3 \pm 23.0^{\mathrm{d}}$ & $211.7 \pm 32.0^{\mathrm{c}}$ & $213.4 \pm 5.87^{c}$ & $217.9 \pm 4.4^{\mathrm{bc}}$ \\
\hline Straw & $85.9 \pm 21.0^{f}$ & $156.2 \pm 47.1^{\mathrm{ab}}$ & $152.6 \pm 46.1^{\mathbf{b}}$ & $159.5 \pm 37.2^{\mathrm{a}}$ & $161.5 \pm 46.6^{\mathrm{a}}$ & $99.0 \pm 15.6^{\mathbf{e}}$ & $113.7 \pm 21.6^{\mathrm{d}}$ & $131.4 \pm 26.6^{c}$ & $133.1 \pm 9.1^{\mathrm{c}}$ & $127.5 \pm 15.3^{\mathrm{c}}$ \\
\hline \multirow[t]{2}{*}{ Grain } & $49.3 \pm 7.2^{\mathrm{h}}$ & $65.7 \pm 10.3^{\mathbf{e}}$ & $63.3 \pm 9.2^{f}$ & $83.5 \pm 0.3^{\mathbf{b}}$ & $78.2 \pm 6.5^{\mathrm{d}}$ & $58.3 \pm 3.1 \mathrm{~g}$ & $66.6 \pm 1.5^{\mathrm{e}}$ & $80.3 \pm 5.3^{c}$ & $80.3 \pm 3.3^{c}$ & $90.4 \pm 11.2^{\mathrm{a}}$ \\
\hline & \multicolumn{10}{|c|}{2012} \\
\hline Plant & $136.4 \pm 11.7^{\mathrm{c}}$ & $118.2 \pm 14.4^{\mathbf{h}}$ & $129.0 \pm 2.7^{\mathbf{e}}$ & $142.5 \pm 0.8^{b}$ & $121.5 \pm 10.5 \mathrm{~g}$ & $158.3 \pm 1.4^{\mathrm{a}}$ & $134.1 \pm 1.6^{\mathrm{d}}$ & $110.8 \pm 2.0^{\mathrm{i}}$ & $125.6 \pm 1.8^{\mathrm{f}}$ & $136.4 \pm 0.9^{c}$ \\
\hline Straw & $65.2 \pm 7.5^{c}$ & $58.7 \pm 6.8^{f}$ & $63.2 \pm 2.8^{c}$ & $69.1 \pm 0.4^{\mathbf{b}}$ & $60.8 \pm 6.4^{\mathrm{e}}$ & $76.9 \pm 4.3^{\mathrm{a}}$ & $65.7 \pm 1.4^{\mathrm{c}}$ & $54.3 \pm 4.0^{\mathrm{g}}$ & $58.0 \pm 2.5^{\mathrm{f}}$ & $64.7 \pm 2.7^{\mathrm{c}}$ \\
\hline Grain & $71.24 \pm 4.1^{\mathrm{c}}$ & $59.48 \pm 7.6 \mathrm{~g}$ & $65.75 \pm 0.3^{e}$ & $73.42 \pm 0.4^{b}$ & $60.7 \pm 4.1^{\mathrm{f}}$ & $81.4 \pm 3.0^{\mathrm{a}}$ & $68.4 \pm 3.0^{\mathrm{d}}$ & $56.5 \pm 2.0^{\mathrm{h}}$ & $67.7 \pm 0.7^{\mathrm{d}}$ & $71.7 \pm 1.9^{\mathrm{c}}$ \\
\hline
\end{tabular}




\subsection{N Use Efficiency Indices, Yield and Grain Protein Content}

The results of the ANOVA, performed on the two years, on NUEy, NUEp and their components and on grain yield (GY) and grain protein content (GPC) are reported in (Supplementary Material Table S3). Saragolla showed higher NUtE, NHI, NUEy and GY values than Sfinge in both years. On the contrary UPE, NUEp and GPC were always higher for Sfinge than for Saragolla (Table 6). In general, GY and GPC values were higher in 2011 than in 2012. Moreover, in 2011, both GY and GPC increased with an increase in N levels, especially in Saragolla for which a positive effect of the three-time fertilization on GPC was observed (Table S4). In 2012, N fertilization did not have a significant effect on GPC; on the contrary, GY increased from N60 to N120, but N90T3 and N120T3 always showed lower values than N90 and N120, respectively. In both years, in general UPE, NUEy and NUEp values decreased with increasing N levels (Table 6); however, in 2011 Sfinge showed the highest UPE value under N90T3, and Saragolla the highest NUEP values under N120T3 (Table S4). As for NUtE, the highest values were observed always under N60 for Saragolla and under N60 and N120 in the first and second year, respectively, for Sfinge (Table S4). Regarding NHI, it showed the highest value under N120T3 in 2011 for Saragolla and under N120 in 2012 for Sfinge. Finally, strobilurin treatment (Table 6) always caused an increase in NHI, NUEy, NUEp, and GY. On the contrary NUtE decreased under STaz in both years, while UPE only in 2011. No effect of STaz on GPC was detected. However, the effect of strobilurin treatment on NUEy, NUEp and their components was different for the two cultivars under examination (Table 7).

In Saragolla, strobilurin treatment caused an increase in UPE, NUEy, NUEp and GY and a decrease in NUtE in both the years. Moreover, an increase in NHI was observed only in 2012. On the contrary, in Sfinge, strobilurin treatment caused a decrease in UPE and NUEp and an increase in NUEy, NUtE and GY. Finally, NHI increased under STaz in 2011 and decreased in 2012.

The effects of strobilurin treatment in relation to nitrogen fertilization are reported in Figure 3 and in (Supplementary Material Figures S2 and S3). In 2011, STaz caused a general increase in NUEy (Figure $3 \mathrm{~A}$ ) under all the $\mathrm{N}$ fertilization processes adopted, with significant differences only under N60 and N90T3. A similar trend was observed for NUEp (Figure 3B), for which the positive effect of STaz under N60 and N90T3 was more evident; moreover, also under N120T3, the STaz value was higher than that of ST0. On the contrary, for UPE (Figure S2A) and NUtE (Figure S2B), the STaz always had a negative effect, except for UPE under N60. Finally, STaz caused a marked increase in NHI (Figure S2C) under N90 and N90T3, a slight increase under N120T3 and a decrease under N60. For GPC, the positive effect of STaz was observed only under N90T3 (Figure S2D).

In 2012 strobilurin treatment caused a significant increase in NUEy (Figure 3C) under all the N fertilization processes adopted, while for NUEp (Figure 3D) and UPE (Figure S3A), this was true under N60, N90 and N120T3. As for NUtE (Figure S3B), the positive effect of STaz was evident only under N90T3 and N120. Finally, the higher NHI (Figure S3C) values were observed under N120 and N120T3 when treated with strobilurin, and under N60 when not treated.

In order to evaluate the effect of strobilurin treatment on the contribution of the two components UPE and NUtE to NUEy and UPE and NHI to NUEp, the ANCOVA analysis was performed on the ln-transformed data. The analysis was significant only for NUEy (Table S5) for the cultivar Saragolla (Table S6). For Saragolla (Table 8), there was a high association between NUEy and UPE $\left(R^{2}=0.63\right)$, while the association between NUEy and NUtE was lower $\left(R^{2}=0.43\right)$. The angular coefficients represent the percentage contribution of each individual component to the total NUEy. In particular, for Saragolla, the contribution of UPE to NUEy was 69\%, and that of NUtE was 31\%. Moreover, the STaz caused an increase in the contribution of UPE and a decrease in the contribution of NUtE to NUEy of $26 \%$. 
Table 6. Effect of cultivar, nitrogen and strobilurin treatment in 2011 and 2012 on uptake efficiency (UPE), nitrogen utilization efficiency (NUtE), nitrogen harvest index (NHI), nitrogen use efficiency for yield (NUEy), nitrogen use efficiency for protein (NUEp), grain yield (GY) and grain protein content (GPC).

\begin{tabular}{|c|c|c|c|c|c|c|c|c|c|c|c|c|c|c|}
\hline $\begin{array}{l}\text { Experimental } \\
\text { Factor }\end{array}$ & UPE & NUtE & NHI & $\begin{array}{c}2011 \\
\text { NUEy } \\
\left(\mathrm{kg} \mathrm{kg}^{-1}\right)\end{array}$ & NUEp & GY & GPC & UPE & NUtE & NHI & $\begin{array}{c}2012 \\
\text { NUEy } \\
\left(\mathrm{kg} \mathrm{kg}^{-1}\right) \\
\end{array}$ & NUEp & GY & GPC \\
\hline & \multicolumn{14}{|c|}{ Cultivar } \\
\hline Saragolla & $1.39 \pm 0.1^{b}$ & $43.8 \pm 2.0^{\mathrm{a}}$ & $0.48 \pm 0.071^{\mathrm{a}}$ & $58.3 \pm 1.5^{\mathrm{a}}$ & $0.67 \pm 0.03^{b}$ & $5.43 \pm 0.12^{\mathrm{a}}$ & $10.1 \pm 0.2^{b}$ & $1.36 \pm 0.1^{b}$ & $35.5 \pm 1.0^{\mathrm{a}}$ & $0.55 \pm 0.010^{\mathrm{a}}$ & $46.5 \pm 2.3^{\mathrm{a}}$ & $0.74 \pm 0.05^{b}$ & $4.20 \pm 0.0^{\mathrm{a}}$ & $8.7 \pm 0.1^{b}$ \\
\hline \multirow[t]{2}{*}{ Sfinge } & $2.95 \pm 0.1^{\mathrm{a}}$ & $14.4 \pm 0.6^{\mathrm{b}}$ & $0.29 \pm 0.061^{\mathrm{b}}$ & $41.5 \pm 2.1 \mathrm{~b}$ & $0.85 \pm 0.03^{\mathrm{a}}$ & $3.74 \pm 0.14^{\mathrm{b}}$ & $16.0 \pm 0.2^{\mathrm{a}}$ & $1.59 \pm 0.1^{\mathrm{a}}$ & $19.7 \pm 0.6^{\mathrm{b}}$ & $0.49 \pm 0.010^{\mathrm{b}}$ & $30.4 \pm 1.5^{b}$ & $0.78 \pm 0.05^{\mathrm{a}}$ & $2.75 \pm 0.0^{\mathrm{b}}$ & $10.4 \pm 0.2^{\mathrm{a}}$ \\
\hline & \multicolumn{14}{|c|}{ Nitrogen Fertilization } \\
\hline N60 & $2.44 \pm 0.3^{a}$ & $33.0 \pm 4.8^{\mathrm{a}}$ & $0.39 \pm 0.018^{b}$ & $66.0 \pm 1.6^{\mathrm{a}}$ & $0.90 \pm 0.07^{a}$ & $3.96 \pm 0.1^{\mathrm{d}}$ & $11.7 \pm 0.9^{\mathrm{d}}$ & $2.46 \pm 0.11^{\mathrm{a}}$ & $24.2 \pm 2.4^{\mathrm{d}}$ & $0.52 \pm 0.01^{\mathrm{a}}$ & $57.0 \pm 3.6^{a}$ & $1.27 \pm 0.05^{\mathrm{a}}$ & $3.42 \pm 0.2 \mathrm{bc}$ & $9.3 \pm 0.4^{\mathrm{a}}$ \\
\hline N90 & $2.23 \pm 0.3^{c}$ & $32.4 \pm 6.0^{\mathrm{a}}$ & $0.37 \pm 0.031^{\mathrm{c}}$ & $51.9 \pm 3.0^{\mathrm{b}}$ & $0.74 \pm 0.05^{c}$ & $4.67 \pm 0.3 b^{c}$ & $12.5 \pm 1.0^{\mathrm{c}}$ & $1.40 \pm 0.08^{\mathrm{b}}$ & $29.9 \pm 3.5^{\mathrm{a}}$ & $0.50 \pm 0.008^{c}$ & $39.0 \pm 2.6^{b}$ & $0.71 \pm 0.05^{b}$ & $3.51 \pm 0.2^{b}$ & $9.3 \pm 0.4^{\mathrm{a}}$ \\
\hline N90T3 & $2.38 \pm 0.3^{b}$ & $30.1 \pm 5.6^{b}$ & $0.38 \pm 0.029 \mathrm{bc}$ & $51.2 \pm 2.6^{b}$ & $0.80 \pm 0.06^{\mathrm{b}}$ & $4.61 \pm 0.2^{c}$ & $13.7 \pm 1.0 \mathrm{ab}$ & $1.33 \pm 0.03^{c}$ & $28.4 \pm 2.6^{\mathrm{b}}$ & $0.51 \pm 0.014^{\mathrm{b}}$ & $37.0 \pm 2.7^{c}$ & $0.68 \pm 0.02^{c}$ & $3.33 \pm 0.2^{c}$ & $9.5 \pm 0.3^{\mathrm{a}}$ \\
\hline N120 & $1.90 \pm 0.1^{\mathrm{d}}$ & $23.6 \pm 3.3^{\mathrm{d}}$ & $0.39 \pm 0.031^{\mathrm{b}}$ & $39.6 \pm 3.2^{c}$ & $0.68 \pm 0.01 \mathrm{e}$ & $4.76 \pm 0.4^{b}$ & $13.1 \pm 1.0^{\mathrm{bc}}$ & $1.12 \pm 0.02^{\mathrm{d}}$ & $28.2 \pm 1.9 b^{c}$ & $0.53 \pm 0.007^{a}$ & $31.1 \pm 1.7^{\mathrm{d}}$ & $0.59 \pm 0.01^{\mathrm{d}}$ & $3.74 \pm 0.2^{\mathrm{a}}$ & $9.7 \pm 0.3^{\mathrm{a}}$ \\
\hline \multirow[t]{2}{*}{ N120T3 } & $1.91 \pm 0.2^{\mathrm{d}}$ & $26.4 \pm 4.3^{c}$ & $0.41 \pm 0.04^{\mathrm{a}}$ & $41.0 \pm 2.7^{c}$ & $0.70 \pm 0.05^{\mathrm{d}}$ & $4.92 \pm 0.3^{\mathrm{a}}$ & $14.1 \pm 1.0^{\mathrm{a}}$ & $1.07 \pm 0.05^{\mathrm{e}}$ & $27.3 \pm 2.8^{c}$ & $0.51 \pm 0.001 \mathrm{~b}$ & $28.1 \pm 2.0^{\mathrm{e}}$ & $0.55 \pm 0.02^{\mathrm{e}}$ & $3.38 \pm 0.2^{c}$ & $10.1 \pm 0.5^{\mathrm{a}}$ \\
\hline & \multicolumn{14}{|c|}{ Strobilurin Treatment } \\
\hline ST0 & $2.23 \pm 0.2^{\mathrm{a}}$ & $31.8 \pm 3.9^{\mathrm{a}}$ & $0.38 \pm 0.021^{b}$ & $48.6 \pm 2.4^{b}$ & $0.72 \pm 0.04^{b}$ & $4.47 \pm 0.2^{b}$ & $12.9 \pm 0.6^{\mathrm{a}}$ & $1.44 \pm 0.09^{b}$ & $27.8 \pm 1.3^{\mathrm{a}}$ & $0.51 \pm 0.004^{b}$ & $36.7 \pm 2.4^{b}$ & $0.74 \pm 0.05^{b}$ & $3.32 \pm 0.1^{b}$ & $9.4 \pm 0.2^{a}$ \\
\hline STaz & $2.11 \pm 0.1^{\mathrm{b}}$ & $26.4 \pm 1.9^{b}$ & $0.40 \pm 0.017 \mathrm{a}$ & $51.3 \pm 2.4^{\mathrm{a}}$ & $0.81 \pm 0.03$ a & $4.70 \pm 0.2^{\mathrm{a}}$ & $13.1 \pm 0.6^{\mathrm{a}}$ & $1.51 \pm 0.11^{\mathrm{a}}$ & $27.4 \pm 2.0^{\mathrm{a}}$ & $0.52 \pm 0.008^{\mathrm{a}}$ & $40.2 \pm 2.5^{a}$ & $0.78 \pm 0.06^{\mathrm{a}}$ & $3.63 \pm 0.1^{\mathrm{a}}$ & $9.8 \pm 0.3^{\mathrm{a}}$ \\
\hline
\end{tabular}

N60, N90 and N120 correspond to 60, 90 and $120 \mathrm{~kg} \mathrm{ha}^{-1}$ of nitrogen applied two times; N90T3, $90 \mathrm{~kg} \mathrm{ha}^{-1}$ of nitrogen applied three times; N120T3, $120 \mathrm{~kg}$ ha ${ }^{-1}$ of nitrogen applied three times. ST0, no strobilurin treatment; STaz, strobilurin treatment. For each experimental factor, values in the column followed by different letters are significantly different at $p \leq 0.05$ according to Tukey's test. Data are reported as means \pm standard errors. 
Table 7. Effect of the interactions between cultivar and strobilurin treatment in 2011 and 2012 on uptake efficiency (UPE), nitrogen utilization efficiency (NUtE), nitrogen harvest index (NHI), nitrogen use efficiency for yield (NUEy), nitrogen use efficiency for protein (NUEp), grain yield (GY) and grain protein content (GPC).

\begin{tabular}{|c|c|c|c|c|}
\hline \multirow[t]{3}{*}{ Crop Season } & \multicolumn{2}{|c|}{ Saragolla } & \multicolumn{2}{|c|}{ Sfinge } \\
\hline & ST0 & STaz & ST0 & STaz \\
\hline & \multicolumn{2}{|c|}{$\left(\mathrm{kg} \mathrm{kg}^{-1}\right)$} & \multicolumn{2}{|c|}{$\left(\mathrm{kg} \mathrm{kg}^{-1}\right)$} \\
\hline \multicolumn{5}{|l|}{2011} \\
\hline UPE & $1.12 \pm 0.03^{d}$ & $1.67 \pm 0.04^{c}$ & $3.33 \pm 0.12^{a}$ & $2.56 \pm 0.16^{b}$ \\
\hline NUtE & $51.7 \pm 2.1^{\mathbf{a}}$ & $35.8 \pm 1.5^{\mathrm{b}}$ & $11.9 \pm 0.8^{\mathrm{d}}$ & $16.9 \pm 0.5^{\mathrm{c}}$ \\
\hline $\mathrm{NHI}$ & $0.49 \pm 0.08^{a}$ & $0.48 \pm 0.01^{\mathbf{a}}$ & $0.27 \pm 0.08^{c}$ & $0.31 \pm 0.04^{b}$ \\
\hline NUEy & $57.4 \pm 2.0^{\mathbf{b}}$ & $59.3 \pm 2.2^{a}$ & $39.8 \pm 2.9^{d}$ & $43.2 \pm 3.2^{c}$ \\
\hline NUEp & $0.55 \pm 0.02^{c}$ & $0.80 \pm 0.02^{\mathbf{b}}$ & $0.90 \pm 0.04^{\mathbf{a}}$ & $0.81 \pm 0.06^{b}$ \\
\hline GY & $5.3 \pm 0.2^{\mathbf{b}}$ & $5.5 \pm 0.1^{\mathrm{a}}$ & $3.6 \pm 0.15^{\mathrm{d}}$ & $3.9 \pm 0.13^{c}$ \\
\hline GPC & $10.0 \pm 0.3^{\mathbf{b}}$ & $10.1 \pm 0.2^{b}$ & $15.9 \pm 0.2^{\mathbf{a}}$ & $16.1 \pm 0.3^{a}$ \\
\hline \multicolumn{5}{|l|}{2012} \\
\hline UPE & $1.23 \pm 0.01^{\mathrm{d}}$ & $1.49 \pm 0.2^{\mathrm{c}}$ & $1.66 \pm 0.1^{\mathrm{a}}$ & $1.53 \pm 0.2^{\mathbf{b}}$ \\
\hline NUtE & $37.1 \pm 1.6^{\mathrm{a}}$ & $33.8 \pm 1.1^{\mathbf{b}}$ & $17.7 \pm 0.3^{\mathrm{d}}$ & $21.7 \pm 0.9^{c}$ \\
\hline $\mathrm{NHI}$ & $0.53 \pm 0.06^{\mathbf{b}}$ & $0.56 \pm 0.03^{a}$ & $0.49 \pm 0.03^{c}$ & $0.48 \pm 0.05^{\mathrm{d}}$ \\
\hline NUEy & $44.6 \pm 3.1^{b}$ & $48.4 \pm 3.4^{\mathrm{a}}$ & $28.9 \pm 2.2^{\mathrm{d}}$ & $31.9 \pm 2.2^{c}$ \\
\hline NUEp & $0.65 \pm 0.1^{d}$ & $0.84 \pm 0.1^{\mathbf{a}}$ & $0.82 \pm 0.1^{\mathbf{b}}$ & $0.72 \pm 0.1^{\mathrm{c}}$ \\
\hline GY & $4.0 \pm 0.15^{b}$ & $4.4 \pm 0.13^{a}$ & $2.6 \pm 0.1^{\mathrm{d}}$ & $2.9 \pm 0.1^{\mathrm{c}}$ \\
\hline GPG & $8.7 \pm 0.2^{b}$ & $8.7 \pm 0.2^{b}$ & $10.0 \pm 0.2^{\mathrm{a}}$ & $10.9 \pm 0.4^{\mathrm{a}}$ \\
\hline
\end{tabular}

ST0, no strobilurin treatment; STaz, strobilurin treatment. For each crop season, values in the row followed by different letters are significantly different at $p \leq 0.05$ according to Tukey's test. Data are reported as means \pm standard errors $(n=15)$.
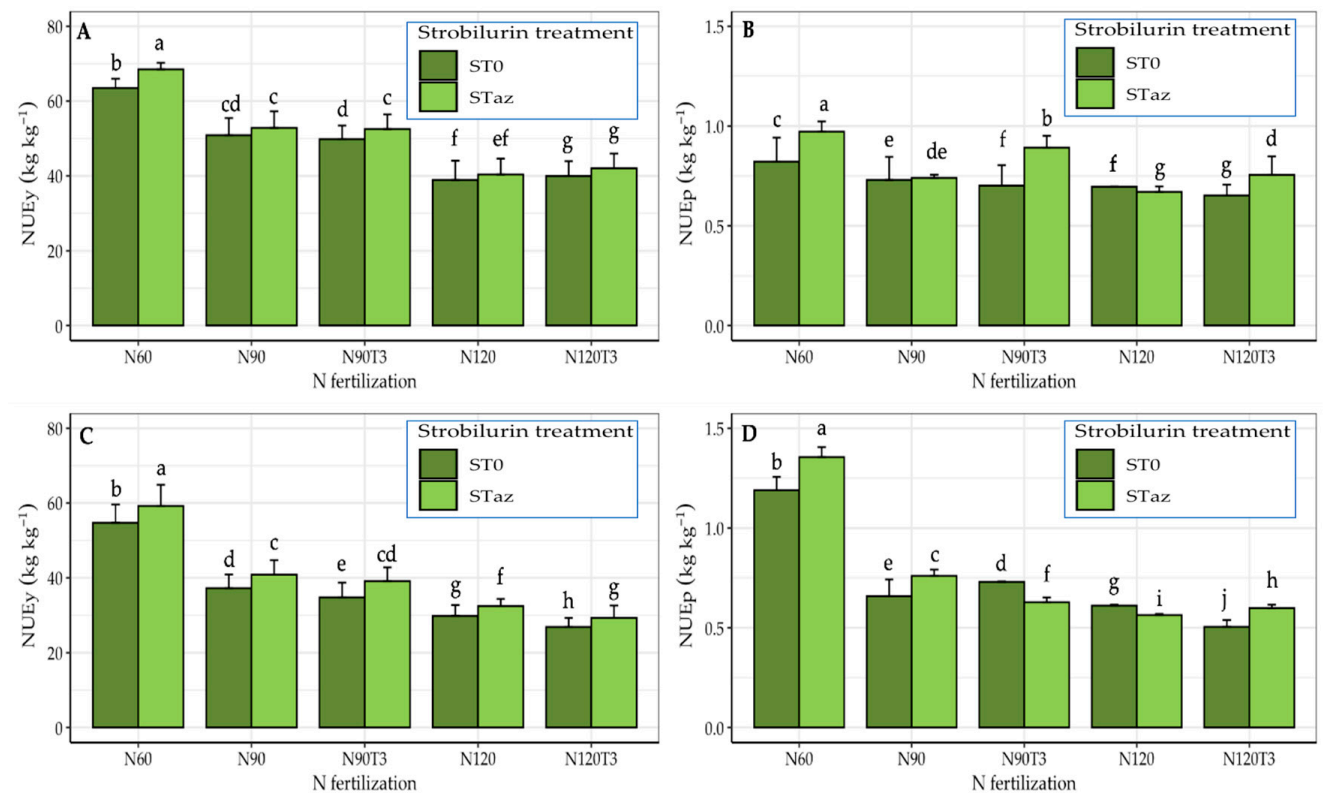

Figure 3. Effect of the interactions between nitrogen fertilization and strobilurin treatment for nitrogen use efficiency for yield (NUEy, (A) and (C) in 2011 and 2012, respectively) and nitrogen use efficiency for protein (NUEp, (B) and (D) in 2011 and 2012, respectively). N60, N90 and N120 correspond to 60, 90 and $120 \mathrm{~kg} \mathrm{ha}^{-1}$ of nitrogen applied two times; N90T3, $90 \mathrm{~kg} \mathrm{ha}^{-1}$ of nitrogen applied three times; $\mathrm{N} 120 \mathrm{~T} 3,120 \mathrm{~kg} \mathrm{ha}^{-1}$ of nitrogen applied three times. ST0, no strobilurin treatment; STaz, strobilurin treatment. Values followed by different letters are significantly different at $p \leq 0.05$ according to Tukey's test. Vertical bars indicate standard errors $(n=6)$. 
Table 8. Effect of strobilurin treatment on nitrogen uptake efficiency (UPE) and nitrogen utilization efficiency (NUtE) contribution to nitrogen use efficiency for yield (NUEy) in the cultivar Saragolla.

\begin{tabular}{ccccccc}
\hline \multirow{2}{*}{ Term } & \multicolumn{3}{c}{ ln UPE versus ln NUEy } & \multicolumn{3}{c}{$\ln$ NUtE versus ln NUEy } \\
& Estimate & Std Error & Prob & Estimate & Std Error & Prob \\
\hline Intercept & -2.47 & 0.37 & $* * *$ & 2.47 & 0.37 & $* * *$ \\
(contribution to ST) & -0.12 & 0.02 & $* * *$ & 0.12 & 0.02 & $* * *$ \\
STo & 0.12 & 0.02 & $* * *$ & -0.12 & 0.02 & $* * *$ \\
STaz & 0.69 & 0.096 & $* * *$ & & & \\
\hline Angular coefficient (contribution to NUEy) & $* .31$ & 0.096 & $* *$ \\
$\quad$ ln NUEy & -0.26 & 0.096 & $* *$ & 0.26 & 0.096 & $* *$ \\
STo $\times$ ln NUEy & 0.26 & 0.096 & $* *$ & -0.26 & 0.096 & $* *$ \\
\hline STaz $\times \ln$ NUEy & $\mathrm{R}^{2}=0.63 * * *$ & RMSE $=0.17$ & $\mathrm{R}^{2}=0.43 * *$ & RMSE $=0.17$ \\
\hline
\end{tabular}

ST0, no strobilurin treatment; STaz, strobilurin treatment; ${ }^{* *}$, significance at $p \leq 0.01$; ${ }^{* * *}$, significant at $p \leq 0.001 ; \mathrm{ns,}$ not significant; $\mathrm{R}^{2}$, coefficient of determination; RMSE, root mean square error.

\section{Discussion}

The two years differed for the rainfall during the crop cycle and mainly during the grain-filling period, the second year being drier than the first one. This caused a lower $\mathrm{N}$ uptake in the second year and consequently a lower $\mathrm{N}$ content in plant and in grain. This was in agreement with the results reported previously by Giuliani et al. [10]. In general, in the second drier year, higher SPAD values were observed, which is in agreement with other studies that reported that SPAD values increased under drought stress and in a warm environment $[33,34]$.

\subsection{Cultivars Effects}

The higher plant, straw and grain $\mathrm{N}$ content values showed by Sfinge in both years were probably due to the higher capacity of this cultivar to uptake $\mathrm{N}$ from the soil, since UPE was always higher for Sfinge than for Saragolla. However, when stressed environment conditions occurred, as in the second year, Sfinge showed a marked UPE decrease associated with a marked decrease in plant, straw and grain N content, while Saragolla showed more consistent behavior. UPE is a component of both NUEy and NUEp and represents the plant's ability to extract nitrogen from the soil depending mainly on root structure and functioning [6,7].

The higher UPE values of Sfinge did not influence NUEy but caused higher NUEp and GPC values than Saragolla. On the contrary, in both years, Saragolla showed higher yield and NUEy values than Sfinge due to higher NUtE values. NUtE can be considered as the capability of the plant to use N stored in the canopy through its remobilization to the sink [7]. In durum wheat, the contribution of $\mathrm{N}$ remobilization from vegetative tissue during grain filling approximately accounted for $53 \%$ to $82 \%$ of grain $\mathrm{N}$ content, with high variability due to differences in climate, soil type effect, cultivars, and crop management $[10,35]$. Thus, during grain filling, the vegetative tissues function as nutrient sources until crop maturity is achieved, especially under dry conditions when a limited $\mathrm{N}$ uptake during the grain-filling period may force the plant to make greater use of its stored $\mathrm{N}$ [36,37]. Under this point of view, senescence of the canopy is essential for the remobilization of N [7] and lower SPAD values, as those observed for Saragolla when compared to Sfinge, especially in the first year, could be linked to higher NUtE and grain yield of the cultivars. Tsialtas et al. [38] also reported that under semiarid conditions, the cultivar with the lower SPAD values was more productive.

Therefore, the two cultivars were very different as the most productive, Saragolla, was characterized by higher NUEy linked to its capability to remobilize the N from the canopy (NUtE). On the other hand, Sfinge showed higher UPE but lower yield and capacity to remobilize the $\mathrm{N}$ from the canopy to the grain during the grain filling (NUtE), since also straw $\mathrm{N}$ content and SPAD values at maturity were higher. Together with higher UPE, Sfinge showed also higher GPC and NUEp values. These results are partially in agreement with those reported for bread wheat by Yu et al. [39] Indeed, the authors, comparing 
six bread wheat cultivars, concluded that the cultivar characterized by high grain yield showed also the highest UPE and NUEy values, while the cultivar that emphasized protein accumulation showed higher NUtE values than the others. On the contrary, in spring barley, comparing cultivars from 75 years of breeding, higher yield values were always associated with an increase in NUtE, while not necessarily matched by increased UPE [40].

\subsection{Nitrogen Fertilization Effects}

In regard to $\mathrm{N}$ management, the SPAD values increased with $\mathrm{N}$ fertilization level and with the split applications; this behavior may be explained with a higher $\mathrm{N}$ content in the plant and thus the increase in chlorophyll concentration [41].

In the first year, the plant, straw and grain $\mathrm{N}$ content increased with increasing nitrogen fertilization level; on the contrary, when conditions of water scarcity increased, as occurred in the second year, the higher doses of $\mathrm{N}$ tended to limit the $\mathrm{N}$ accumulation both in straw and in grain.

As for NUEy, NUEp and their component UPE, similarly to other studies [10,27,42-44], N fertilizer application led to a general decrease in both years.

The $\mathrm{N}$ fertilizer given three times (N90T3 and N120T3) had a positive effect in the first year only on N grain content, NUEp and GPC, while no significant effect was observed for NUEy, despite the fact that it is reported in the literature that splitting the amount of $\mathrm{N}$ fertilizer increases the efficiency of nitrogen use efficiency [45]. However, when giving $\mathrm{N}$ three times, a negative effect in the second drier year was always observed, indicating that under drought conditions, late $\mathrm{N}$ fertilizations were not useful for the plant, worsening the water stress conditions. This was confirmed also by the lower values of GY, NUEy, NUEp and their components observed in the second year under NT3 conditions. Moreover, the lower rainfall registered in the second year canceled the beneficial effect of $\mathrm{N}$ given three times on the GPC since no significant differences were observed. Several studies have shown that in wheat, applications of $\mathrm{N}$ later in the season (spring) and near anthesis are more effective than earlier applications in enhancing GPC [46-48] and sometimes also GY [49,50]; thus, also N fertilizer recovery and efficiency were reported to increase with late applications when compared to fall applications during sowing [51-53].

In our study, this was true only for NUEp in the first year; moreover, we found that the effect of $\mathrm{N}$ given three times on nitrogen use efficiency was strongly linked with the weather conditions. Indeed, the limited moisture, due to dry weather and rainfed conditions, caused limited root exploitation and therefore a limited UPE, N plant content, and NHI [10]. According to Velasco et al. [54], splitting the $\mathrm{N}$ rate would be a strategy to increase $\mathrm{N}$ efficiency and thus reduce $\mathrm{N}$ losses mainly in no water stress conditions.

\subsection{Strobilurin Effect}

Usually, fungicides are used to control and prevent diseases; in this paper, strobilurin treatment was considered only to evaluate its physiological effects [55-57], as the weather conditions recorded in the two years of study were not favorable to fungal diseases. The SPAD values recorded during the grain filling period confirmed that strobilurin had an effect on the duration of the wheat canopy [58] and therefore on the duration that the plant remained green [59-61], probably due to the reduction of ethylene synthesis and the protective effect of the antioxidative system [62], which postpones the degradation of chlorophyll and therefore the yellowing of the leaves [63].

The effect of strobilurin treatment was different for the two cultivars under examination, which indicates that there was genetic difference between Saragolla and Sfinge for response to STaz. In Sfinge, surprisingly, strobilurin treatment caused a decrease in the straw and grain $\mathrm{N}$ content. Indeed, for this cultivar, the higher $\mathrm{N}$ uptake ability discussed above decreased under strobilurin treatment. This result disagreed with the literature, in which it is reported that strobilurin fungicides can increase soil N uptake [57,59]. Furthermore, Khole et al. [22] reported that strobilurin stimulated nitrate uptake in hydroponically grown wheat plants. In our experimental conditions, the increase in 
NUtE under strobilurin treatment (about $42 \%$ in 2011 and 23\% in 2012) seems to have compensated for the decrease in UPE (-23\% in 2011 and $-8 \%$ in 2012) as the NUEy increased, especially in the first year, as well as the grain yield. Nitrogen utilization efficiency depends on both the nitrogen source-to-sink remobilization efficiency and nitrogen assimilation efficiency at the sink [64]. However, the mechanism of source-to-sink nitrogen remobilization in wheat remains unclear [39]. The greater amount of nitrogen adsorbed is transported in the form of nitrate and ammonium and then assimilated in the leaves [65]. It has been demonstrated that NADH-nitrate reductase, which catalyzes the first step in nitrate assimilation, is the relevant target for the yield effect of strobilurin [66]. Khole et al. [22] reported that when wheat plants (Triticum aestivum L.) grown under hydroponic conditions were treated by strobilurin, nitrite and ammonia were accumulated in the leaves during the night period due to the fact that nitrate reductase was not dark-inactivated as in the control plants. Moreover, it is reported that strobilurin could cause an additional activation of nitrato-reductase, which is probably mediated via acidification of the cytoplasm [17].

However, the decrease in UPE observed in Sfinge under STaz strongly influenced the values of NUEp which always decreased, despite the increase in the NHI component in the first year. In Saragolla, the opposite behavior of strobilurin treatment when compared to Sfinge was observed. The significant increase in straw and grain $\mathrm{N}$ content under strobilurin treatment was due to the positive effect of the treatment on UPE, especially in the first year when the environment conditions for a higher N uptake were favorable ( $49 \%$ in 2011 and $21 \%$ in 2012).

The UPE increase led to an increase in NUEy, NUEp and GY, more evident in the first year, despite strobilurin surprisingly having a negative effect on NUtE (-31\% in 2011 and $-9 \%$ in 2012). Therefore, for Saragolla, the increase in plant $\mathrm{N}$ content and yield due to strobilurin can be accounted for by the increase in UPE. The results presented in the current paper showed that the positive effect reported in literature for strobilurin on uptake and remobilization efficiency ultimately depends on the cultivars, and, thus, the interaction between strobilurin treatment and cultivar seems to be very important.

Furthermore, the results of ANCOVA analysis showed a significant effect of strobilurin treatment on the contribution of the two components only to NUEy for the cultivar Saragolla. In agreement with several authors $[28,30,67,68]$, a higher contribution of UPE $(69 \%)$ than NUtE $(31 \%)$ to NUEy was observed. The present study provides new evidence to suggest that strobilurin significantly and positively affected the contribution of UPE (from 69\% to 95\%) and negatively that of NUtE (from 31\% to $5 \%$ ) to NUEy only in Saragolla, while no significant effects were detected for Sfinge.

Finally, in our experimental conditions, it is important to note that, for both cultivars, no reduction in GPC was observed, despite the fact that a yield increase was promoted by strobilurin application [19]. This is contrary to the best-known negative relationship between protein concentration and yields of wheat cultivars $[10,69,70]$. The improvement in the duration of grain $\mathrm{N}$ accumulation during grain filling following strobilurin application, as shown by the increase in the SPAD values, probably helped to maintain grain protein concentration, as yield increased [71], confirming that the effect of strobilurin on protein concentration is small [57].

Regarding the effects of strobilurin treatment in relation to $\mathrm{N}$ fertilization, no clear trend was observed for plant and straw $\mathrm{N}$ content, while the effect of the treatment on the grain $\mathrm{N}$ content was clearer. The strobilurin caused a significant increase in grain N content under N60 in both years $(18 \%$ and $14 \%$ in the first and second year, respectively) and under N90 in the second drier year (15\%). Concurrently, STaz caused an increase in both NUEy and NUEp under N60 and N90T3 in the first year. This is a very interesting result in regard to sustainable agriculture, since strobilurin seems to emphasize the effect of low nitrogen levels. Moreover, in the second drier year, strobilurin treatment determined higher NUEy values under all the nitrogen fertilization processes adopted and NUEp under N60, N90 and N120T3. This result was also very interesting, since in the Mediterranean area, situations of drought are predicted due to the ongoing climate change.

Moreover, in the first year, the STaz determined a positive effect of the $\mathrm{N}$ given three times for grain N content ( $27 \%$ and $16 \%$ for $\mathrm{N} 90 \mathrm{~T} 3$ and N120T3, respectively); the value observed under N90T3 
was very similar to that reached under N120 without strobilurin treatment. Once again, this result is very important because strobilurin application could reduce the $\mathrm{N}$ rate application from 120 to $90 \mathrm{~kg} \mathrm{ha}^{-1}$ with excellent results.

Finally, the negative effect of the nitrogen distributed three times observed in the second drier year on most of the parameters considered was overcome following strobilurin application.

\section{Conclusions}

The influence of strobilurin treatment on durum wheat $\mathrm{N}$ use efficiency for yield and grain protein was investigated by examining the interaction with cultivar and different $\mathrm{N}$ fertilization treatments under Mediterranean conditions. We partially confirmed results of previous experiments investigating the relationships between strobilurin and nitrogen use efficiency in durum wheat. In addition, our findings showed that the positive effect reported in the literature for strobilurin on uptake and remobilization efficiency ultimately depends on the cultivars, and, thus, the interaction between strobilurin treatment and cultivar seems to be very important. Indeed, strobilurin had a positive effect on UPE, NUEy and NUEp in Saragolla, which is a cultivar characterized by high yield and low grain protein content, and on NUtE and NUEy in Sfinge, which is a cultivar characterized by low yield and high grain protein content. Moreover, we provide new evidence to suggest that strobilurin positively affected the contribution of UPE and negatively that of NUtE to NUEy only in Saragolla.

As for the interaction with $\mathrm{N}$ fertilization, we observed that strobilurin could reduce the $\mathrm{N}$ rate application from 120 to $90 \mathrm{~kg} \mathrm{ha}^{-1}$ given three times with satisfactory results in terms of grain $\mathrm{N}$ content. The most interesting results were observed in the second drier year, when only $27 \mathrm{~mm}$ of rain fell during the grain-filling period. In this condition, strobilurin determined higher NUEy and NUEp values under most of the $\mathrm{N}$ fertilization processes adopted. These results are very interesting since conditions of drought are predicted in the Mediterranean area due to the ongoing climate change. Thus, our results improved the knowledge related to complexity of managing durum wheat nitrogen fertilization in sustainable agricultural systems under Mediterranean climate conditions.

Supplementary Materials: The following are available online at http://www.mdpi.com/2073-4395/10/10/1508/s1, Figure S1. Daily rainfall and maximum and minimum temperatures for the two years under examination: 2011 (a) and 2012 (b). Figure S2. Effect of the interaction nitrogen fertilization x strobilurin treatment in 2011 for uptake efficiency (UPE, A), nitrogen utilization efficiency (NUtE, B), nitrogen harvest index (NHI, C), and grain protein content (GPC, D). Figure S3. Effect of the interaction nitrogen fertilization x strobilurin treatment in 2012 for uptake efficiency (UPE, A), nitrogen utilization efficiency (NUtE, B), and nitrogen harvest index (NHI, C). Table S1. Mean square relative to genotype $(\mathrm{G})$, nitrogen fertilization $(\mathrm{N})$, strobilurin treatment (ST) and their interactions resulting from analysis of variance (ANOVA) performed in two crop seasons on straw, grain and plant nitrogen content. Table S2. Effect of the interactions nitrogen fertilization x cultivar in 2011 and 2012 for plant, straw and grain $\mathrm{N}$ content $\left(\mathrm{kg} \mathrm{kg}^{-1}\right)$. Table S3. Mean square relative to genotype $(\mathrm{G})$, nitrogen fertilization $(\mathrm{N})$, strobilurin treatment (ST) and their interactions resulting from analysis of variance (ANOVA) performed in two crop seasons on grain yield (GY), grain protein content (GPC), NUEy, NUEp and their components. Table S4. Effect of the interactions nitrogen fertilization x cultivar in 2011 and 2012 on uptake efficiency (UPE), nitrogen utilization efficiency (NUtE), nitrogen harvest index (NHI), nitrogen use efficiency for yield (NUEy), nitrogen use efficiency for protein (NUEp), grain yield (GY) and grain protein content (GPC). Table S5. Results of the ANCOVA procedure performed on ln-transformed data using NUEy and NUEp as the regressor in relation to strobilurin treatment. Table S6. Results of the ANCOVA procedure performed on ln-transformed data using NUEy as the regressor in relation to strobilurin treatment for the two cultivars under study.

Author Contributions: Conceptualization, M.M.G. methodology, M.M.G. and G.G., P.D.V. validation, M.M.G., G.G. formal analysis, F.C., G.G. and M.M.G. investigation, F.C., A.G. writing-original draft preparation, F.C. writing—review and editing, M.M.G., G.G., P.D.V. visualization, A.G. and F.C. supervision, M.M.G., G.G. project administration, M.M.G. All authors have read and agreed to the published version of the manuscript.

Funding: This research received no external funding.

Acknowledgments: We would like to show our gratitude to Eugenio Nardella (UNIFG) and to Antonio Colecchia (CREA-CI) for their skilful technical assistance during the experimental trials.

Conflicts of Interest: The authors declare no conflict of interest. 


\section{References}

1. ISTAT. 2018. Available online: http://dati.istat.it (accessed on 12 May 2020).

2. Todorovic, M.; Caliandro, A.; Albrizio, R. Irrigated agriculture and water use efficiency in Italy. In Options Méditerranéennes: Série B; Lamaddalena, N., Shatanawi, M., Todorovic, M., Bogliotti, C., Albrizio, R., Eds.; Etudes et Recherches; Water Use Efficiency and Water Productivity: WASAMED Project; CIHEAM: Bari, Italy, 2007; Volume 57, pp. 101-136.

3. Del Moral, L.F.; Rharrabti, Y.; Villegas, D.; Royo, C. Evaluation of grain yield and its components in durum wheat under Mediterranean conditions. Agron. J. 2003, 95, 266-274. [CrossRef]

4. Raun, W.; Johnson, G.V. Improving nitrogen use efficiency for cereal production. Agron. J. 1999, 91, 357-363. [CrossRef]

5. Kant, S.; Bi, Y.-M.; Rothstein, S.J. Understanding plant response to nitrogen limitation for the improvement of crop nitrogen use efficiency. J. Exp. Bot. 2011, 62, 1499-1509. [CrossRef]

6. Masclaux-Daubresse, C.; Daniel-Vedele, F.; Dechorgnat, J.; Chardon, F.; Gaufichon, L.; Suzuki, A. Nitrogen uptake, assimilation and remobilization in plants: Challenges for sustainable and productive agriculture. Ann. Bot. 2010, 105, 1141-1157. [CrossRef]

7. Hawkesford, M.J. Reducing the reliance on nitrogen fertilizer for wheat production. J. Cereal Sci. 2014, 59, 276-283. [CrossRef]

8. Moll, R.H.; Kamprath, E.J.; Jackson, W.A. Analysis and interpretation of factors which contribute to efficiency of nitrogen utilization. Agron. J. 1982, 74, 562-564. [CrossRef]

9. Le Gouis, J.; Béghin, D.; Heumez, E.; Pluchard, P. Genetic differences for nitrogen uptake and nitrogen utilisation efficiencies in winter wheat. Eur. J. Agron. 2000, 12, 163-173. [CrossRef]

10. Giuliani, M.M.; Giuzio, L.; De Caro, A.; Flagella, Z. Relationships between nitrogen utilization and grain technological quality in durum wheat: I. Nitrogen translocation and nitrogen use efficiency for protein. Agron. J. 2011, 103, 1487-1494. [CrossRef]

11. Cormier, F.; Foulkes, M.; Hirel, B.; Gouache, D.; Moënne-Loccoz, Y.; Le Gouis, J. Breeding for increased nitrogen-use efficiency: A review for wheat (T. aestivum L.). Plant Breed. 2016, 135, 255-278. [CrossRef]

12. Giambalvo, D.; Ruisi, P.; Di Miceli, G.; Frenda, A.S.; Amato, G. Nitrogen use efficiency and nitrogen fertilizer recovery of durum wheat genotypes as affected by interspecific competition. Agron. J. 2010, 102, 707-715. [CrossRef]

13. Arduini, I.; Masoni, A.; Ercoli, L.; Mariotti, M. Grain yield, and dry matter and nitrogen accumulation and remobilization in durum wheat as affected by variety and seeding rate. Eur. J. Agron. 2006, 25, 309-318. [CrossRef]

14. Du Jardin, P. Plant biostimulants: Definition, concept, main categories and regulation. Sci. Hortic. 2015, 196, 3-14. [CrossRef]

15. Sauter, H.; Steglich, W.; Anke, T. Strobilurins: Evolution of a new class of active substances. Angew. Chem. Int. Ed. 1999, 38, 1328-1349. [CrossRef]

16. Bartlett, D.W.; Clough, J.M.; Godwin, J.R.; Hall, A.A.; Hamer, M.; Parr-Dobrzanski, B. The strobilurin fungicides. Pest. Manag. Sci. 2002, 58, 649-662. [CrossRef]

17. Glaab, J.; Kaiser, W.M. Increased nitrate reductase activity in leaf tissue after application of the fungicide Kresoxim-methyl. Planta 1999, 207, 442-448. [CrossRef]

18. Nason, M.A.; Farrar, J.; Bartlett, D. Strobilurin fungicides induce changes in photosynthetic gas exchange that do not improve water use efficiency of plants grown under conditions of water stress. Pest Manag. Sci. 2007, 63, 1191-1200. [CrossRef]

19. Ruske, R.; Gooding, M.J.; Jones, S.A. The effects of triazole and strobilurin fungicide programmes on nitrogen uptake, partitioning, remobilization and grain N accumulation in winter wheat cultivars. J. Agric. Sci. 2003, 140, 395-407. [CrossRef]

20. Gooding, M.J.; Gregory, P.J.; Ford, K.E.; Pepler, S. Fungicide and cultivar affect post-anthesis patterns of nitrogen uptake, remobilization and utilization efficiency in wheat. J. Agric. Sci. 2005, 143, 503-518. [CrossRef]

21. Gooding, M.J.; Gregory, P.; Ford, K.; Ruske, R. Recovery of nitrogen from different sources following applications to winter wheat at and after anthesis. Field Crops Res. 2007, 100, 143-154. [CrossRef] 
22. Köhle, H.; Grossmann, K.; Jabs, T.; Gerhard, M.; Kaiser, W.; Glaab, J.; SEEHAUS, K.; Herms, S. Physiological effects of the strobilurin fungicide F 500 on plants. In Modern Fungicides and Antifungal Compounds III; Agroconcept GmbH: Bonn, Germany, 2003.

23. Colecchia, S.A.; Basso, B.; Cammarano, D.; Gallo, A.; Mastrangelo, A.M.; Pontieri, P.; Del Giudice, L.; Pignone, M.; De Vita, P. On the relationship between N management and grain protein content in six durum wheat cultivars in Mediterranean environment. J. Plant Interact. 2013, 8, 271-279. [CrossRef]

24. Lancashire, P.D.; Bleiholder, H.; Boom, T.V.D.; Langelüddeke, P.; Stauss, R.; Weber, E.; Witzenberger, A. A uniform decimal code for growth stages of crops and weeds. Ann. Appl. Biol. 1991, 119, 561-601. [CrossRef]

25. Noulas, C.; Herrera, J.M.; Tziouvalekas, M.; Qin, R.; Ruijun, Q. Agronomic assessment of nitrogen use efficiency in spring wheat and interrelations with leaf greenness under field conditions. Commun. Soil Sci. Plant Anal. 2018, 49, 763-781. [CrossRef]

26. Shapiro, C.A.; Schepers, J.S.; Francis, D.D.; Shanahan, J.F. Using a Chlorophyll Meter to Improve N Management; Publ. G1632; Univ. of Nebraska Coop. Ext. Service: Lincoln, NE, USA, 2006.

27. López-Bellido, L.; López-Bellido, R.J.; Redondo, R. Nitrogen efficiency in wheat under rainfed Mediterranean conditions as affected by split nitrogen application. Field Crops Res. 2005, 94, 86-97. [CrossRef]

28. Van Sanford, D.A.; Mackown, C.T. Variation in nitrogen use efficiency among soft red winter wheat genotypes. Theor. Appl. Genet. 1986, 72, 158-163. [CrossRef] [PubMed]

29. Box, G.E.P.; Cox, D.R. An analysis of transformations. J. R. Stat. Soc. B 1964, 26, 211-243. [CrossRef]

30. Ortiz-Monasterio, J.I.R.; Peñna, R.J.; Sayre, K.D.; Rajaram, S. CIMMYT's genetic progress in wheat grain quality under four nitrogen rates. Crop Sci. 1997, 37, 892-898. [CrossRef]

31. R Core Team. R: A Language and Environment for Statistical Computing; R Foundation for Statistical Computing: Vienna, Austria, 2018; Available online: https://www.R.-project.org (accessed on 22 February 2020).

32. Wickham, H. Ggplot2: Elegant Graphics for Data Analysis, 2nd ed.; Springer: New York, NY, USA, 2009. [CrossRef]

33. Ommen, O.; Donnelly, A.; Vanhoutvin, S.; Van Oijen, M.; Manderscheid, R. Chlorophyll content of spring wheat flag leaves grown under elevated $\mathrm{CO}_{2}$ concentrations and other environmental stresses within the 'ESPACE-wheat' project. Eur. J. Agron. 1999, 10, 197-203. [CrossRef]

34. Yıldırım, M.; Koç, M.; Akıncı, C.; Barutçular, C.; Yildirim, M. Variations in morphological and physiological traits of bread wheat diallel crosses under timely and late sowing conditions. Field Crops Res. 2013, 140, 9-17. [CrossRef]

35. Masoni, A.; Ercoli, L.; Mariotti, M.; Arduini, I. Post-anthesis accumulation and remobilization of dry matter, nitrogen and phosphorus in durum wheat as affected by soil type. Eur. J. Agron. 2007, 26, 179-186. [CrossRef]

36. Barbottin, A.; LeComte, C.; Bouchard, C.; Jeuffroy, M.H. Nitrogen remobilization during grain filling in wheat: Genotypic and environmental effects. Crop Sci. 2005, 45, 1141-1150. [CrossRef]

37. Muurinen, S.; Kleemola, J.; Peltonen-Sainio, P. Accumulation and translocation of nitrogen in spring cereal cultivars differing in nitrogen use efficiency. Agron. J. 2007, 99, 441-449. [CrossRef]

38. Tsialtas, I.T.; Theologidou, G.; Karaoglanidis, G. Effects of pyraclostrobin on leaf diseases, leaf physiology, yield and quality of durum wheat under Mediterranean conditions. Crop Prot. 2018, 113, 48-55. [CrossRef]

39. Yu, Z.; Islam, S.; She, M.; Diepeveen, D.A.; Zhang, Y.; Tang, G.; Zhang, J.; Juhász, A.; Yang, R.; Ma, W. Wheat grain protein accumulation and polymerization mechanisms driven by nitrogen fertilization. Plant J. 2018, 96, 1160-1177. [CrossRef]

40. Bingham, I.; Karley, A.; White, P.J.; Thomas, W.; Russell, J. Analysis of improvements in nitrogen use efficiency associated with 75 years of spring barley breeding. Eur. J. Agron. 2012, 42, 49-58. [CrossRef]

41. Espindula, M.C.; Rocha, V.S.; Fontes, P.C.R.; Da Silva, R.C.C.; De Souza, L.T. Effect of nitrogen and trinexapac-ethyl rates on the SPAD index of wheat leaves. J. Plant Nutr. 2009, 32, 1956-1964. [CrossRef]

42. Giambalvo, D.; Stringi, L.; Durante, G.; Amato, G.; Frenda, A.S. Nitrogen Efficiency Component Analysis in Wheat Under Rainfed Mediterranean Conditions: Effects of Crop Rotation and Nitrogen Fertilization. Mediterranean Rainfed Agriculture: Strategies for Sustainability; Mediterranean Agronomic Institute of Zaragoza: Zaragoza, Spain, 2004; pp. 169-173.

43. López-Bellido, L.; López-Bellido, R.J.; López-Bellido, F.J. Fertilizer nitrogen efficiency in durum wheat under rainfed mediterranean conditions: Effect of split application. Agron. J. 2006, 98, 55-62. [CrossRef] 
44. Cabrera-Bosquet, L.; Molero, G.; Bort, J.; Nogués, S.; Araus, J.L. The combined effect of constant water deficit and nitrogen supply on WUE, NUE and $\triangle 13 \mathrm{C}$ in durum wheat potted plants. Ann. Appl. Biol. 2007, 151, 277-289. [CrossRef]

45. López-Bellido, L.; Muñoz-Romero, V.; Benítez-Vega, J.; Fernández-García, P.; Redondo, R.; López-Bellido, R.J. Wheat response to nitrogen splitting applied to a Vertisols in different tillage systems and cropping rotations under typical Mediterranean climatic conditions. Eur. J. Agron. 2012, 43, 24-32. [CrossRef]

46. Ottman, M.J.; Doerge, T.A.; Martin, E.C. Durum grain quality as affected by nitrogen fertilization near anthesis and irrigation during grain fill. Agron. J. 2000, 92, 1035-1041. [CrossRef]

47. Bly, A.G.; Woodard, H.J. Foliar nitrogen application timing influence on grain yield and protein concentration of hard red winter and spring wheat. Agron. J. 2003, 95, 335-338. [CrossRef]

48. Orloff, S.; Wright, S.; Ottman, M. Nitrogen management impacts on wheat yield and protein. In Proceedings of the California Alfalfa \& Grains Symposium, Sacramento, CA, USA, 11-12 December 2012.

49. Borghi, B. The Varietal Evolution of Common Wheat in Italy in the Last Century. Wheat From Rieti Worldwide; Atti Convegno: Rieti, Italy, 2000.

50. Blankenau, K.; Olfs, H.W.; Kuhlmann, H. Strategies to improve the use efficiency of mineral fertilizer nitrogen applied to winter wheat. J. Agron. Crop Sci. 2002, 188, 146-154. [CrossRef]

51. Mahler, R.L.; Koehler, F.E.; Lutcher, L.K. Nitrogen source, timing of application, and placement: Effects on winter wheat production. Agron. J. 1907, 86, 637-642. [CrossRef]

52. Sieling, K.; Schröder, H.; Finck, M.; Hanus, H. Yield, N uptake, and apparent N-use efficiency of winter wheat and winter barley grown in different cropping systems. J. Agric. Sci. 1998, 131, 375-387. [CrossRef]

53. Limaux, F.; Recous, S.; Meynard, J.M.; Guckert, A. Relationship between rate of crop growth at date of fertiliser $\mathrm{N}$ application and fate of fertiliser N applied to winter wheat. Plant Soil 1999, 214, 49-59. [CrossRef]

54. Velasco, J.L.; Rozas, H.S.; Echeverría, H.E.; Barbieri, P.A. Optimizing fertilizer nitrogen use efficiency by intensively managed spring wheat in humid regions: Effect of split application. Can. J. Plant Sci. 2012, 92, 847-856. [CrossRef]

55. Diaz-Espejo, A.; Cuevas, M.V.; Ribas-Carbo, M.; Flexas, J.; Martorell, S.; Fernández, J.E. The effect of strobilurins on leaf gas exchange, water use efficiency and ABA content in grapevine under field conditions. J. Plant Physiol. 2012, 169, 379-386. [CrossRef]

56. Blandino, M.; Haidukowski, M.; Pascale, M.; Plizzari, L.; Scudellari, D.; Reyneri, A.; Haidukowski, M. Integrated strategies for the control of Fusarium head blight and deoxynivalenol contamination in winter wheat. Field Crops Res. 2012, 133, 139-149. [CrossRef]

57. Amaro, A.C.E.; Baron, D.; Ono, E.O.; Rodrigues, J.D. Physiological effects of strobilurin and carboxamides on plants: An overview. Acta Physiol. Plant 2019, 42, 1-10. [CrossRef]

58. Ishikawa, S.; Hare, M.C.; Kettlewell, P.S. Effects of strobilurin fungicide programmes and fertilizer nitrogen rates on winter wheat: Severity ofSeptoria tritici, leaf senescence and yield. J. Agric. Sci. 2011, 150, 411-426. [CrossRef]

59. Bryson, R.J.; Leandro, L.; Jones, D.R. The physiological effects of kresoxim-methyl on wheat leaf greenness and the implications for crop yield. In The BCPC Conference: Pests and Diseases, Proceedings of the International Conference Held at the Brighton Hilton Metropole Hotel, Brighton, UK, 13-16 November 2000; British Crop Protection Council: Farnham, UK, 2000; Volume 2, pp. 739-746. ISBN 1901396592.

60. Gooding, M.J.; Dimmock, J.P.R.E.; France, J.; Jones, S.A. Green leaf area decline of wheat flag leaves: The influence of fungicides and relationships with mean grain weight and grain yield. Ann. Appl. Biol. 2000, 136, 77-84. [CrossRef]

61. Ruske, R.; Gooding, M.J.; Dobraszczyk, B. Effects of triazole and strobilurin fungicide programmes, with and without late-season nitrogen fertiliser, on the baking quality of Malacca winter wheat. J. Cereal Sci. 2004, 40, 1-8. [CrossRef]

62. Zhang, Z.; Li, F.; Li, D.; Zhang, H.; Huang, R. Expression of ethylene response factor JERF1 in rice improves tolerance to drought. Planta 2010, 232, 765-774. [CrossRef] [PubMed]

63. Dunne, B. Strobilurin use on cereals. Crop. Prot. 2005, 23, 17-20.

64. Jamieson, P.; Semenov, M.A. Modelling nitrogen uptake and redistribution in wheat. Field Crops Res. 2000, 68, 21-29. [CrossRef]

65. Xu, G.; Fan, X.; Miller, A.J. Plant nitrogen assimilation and use efficiency. Annu. Rev. Plant Biol. 2012, 63, 153-182. [CrossRef] 
66. Kanungo, M.; Joshi, J. Impact of pyraclostrobin (F-500) on crop plants. Plant Sci. Today 2014, 1, $174-178$. [CrossRef]

67. Dhugga, K.S.; Waines, J.G. Analysis of nitrogen accumulation and use in bread and durum wheat. Crop Sci. 1989, 29, 1232-1239. [CrossRef]

68. Aynehband, A.; Asadi, S.; Rahnama, A. Nitrogen use efficiency assessment under intra-and inter-specific competitions stress. J. Plant Physiol. Breed. 2014, 4, 9-21.

69. Simmonds, N.W. The relation between yield and protein in cereal grain. J. Sci. Food Agric. 1995, 67, 309-315. [CrossRef]

70. Gagliardi, A.; Carucci, F.; Masci, S.; Flagella, Z.; Gatta, G.; Giuliani, M.M. Effects of genotype, growing season and nitrogen level on gluten protein assembly of durum wheat grown under mediterranean conditions. Agronomy 2020, 10, 755. [CrossRef]

71. Dimmock, J.P.R.E.; Gooding, M.J. The influence of foliar diseases, and their control by fungicides, on the protein concentration in wheat grain: A review. J. Agric. Sci. 2002, 138, 349-366. [CrossRef]

(C) 2020 by the authors. Licensee MDPI, Basel, Switzerland. This article is an open access article distributed under the terms and conditions of the Creative Commons Attribution (CC BY) license (http://creativecommons.org/licenses/by/4.0/). 